JURNAL PENDIDIKAN, p-ISSN 2715-095X, e-ISSN 2686-5041

Volume 29, No.3, Nopember 2020 (295-304)

Online: http://journal.univetbantara.ac.id/index.php/jp

\title{
Meningkatkan Prestasi Belajar Seni Musik Melalui Model Pembelajaran Kooperatif Time Token Pada Materi Pokok Akor Siswa Kelas VIII B Semester I SMP Negeri 3 Nguter
}

\author{
Ratna Diah Yuwani \\ Guru SMP Negeri 3 Nguter, Email: ratnayuwani@gmail.com
}

\begin{abstract}
Abstrak: Penelitian ini bertujuan untuk meningkatkan prestasi belajar seni musik materi pokok akor pada kelas VIII B SMP Negeri 3 Nguter tahun pelajaran 2017/2018 dengan penerapan model pembelajaran kooperatif Time Token. Penelitian ini adalah Penelitian Tindakan Kelas (PTK) yang dilaksanakan di kelas VIIIB SMP Negeri 3 Nguter, semester I tahun pelajaran 2017/2018, dengan jumlah siswa sebanyak 22 orang. Teknik pengumpulan data yang digunakan adalah tes, observasi, dan dokumentasi. Tahap-tahap analisis data dalam penelitian ini adalah pengumpulan data, reduksi data, penyajian data, dan penarikan kesimpulan. Indikator kinerja dari penelitian ini adalah sebagai berikut: (1) Siswa dianggap mencapai ketuntasan belajar apabila mencapai lebih dari atau sama dengan KKM (KKM 70), (2) Pembelajaran dianggap berhasil apabila tingkat ketuntasan kelas mencapai lebih dari atau sama dengan $85 \%$, dan (3) Pembelajaran dianggap berhasil apabila siswa secara klasikal rata-rata mencapai lebih dari atau sama dengan 80. Berdasarkan penelitian yang telah dilakukan, dapat disimpulkan bahwa dengan model pembelajaran kooperatif Time Token dapat meningkatkan prestasi belajar seni musik materi pokok akor pada siswa kelas VIIIB SMP Negeri 3 Nguter. Hal ini dapat dilihat dari persentase ketuntasan belajar siswa, yaitu: sebelum tindakan 15 siswa atau $68,2 \%$, pada siklus I sebanyak 17 siswa atau $77,3 \%$ dan pada siklus II sebanyak 21 siswa atau 95,5\%. Sedangkan rata-rata prestasi belajar Seni musik materi pokok akor siswa sebelum tindakan sebesar 70,2, pada siklus I sebesar 73,2, dan pada siklus II sebesar 82,7.
\end{abstract}

Kata-kata Kunci: Model pembelajaran kooperatif Time Token, prestasi belajar seni musik materi pokok akor.

\section{Improving The Learning Achievement of Musics on Main Acord Material Using Time Token Cooperative Learning Model for Students of VIIIB Semester I SMP Negeri 3 Nguter 2017/2018 Academic Year}

\section{Ratna Diah Yuwani}

The Teacher of SMP Negeri 3 Nguter,Email: ratnayuwani@gmail.com

\begin{abstract}
The purpose of this classroom action research is to improve students' learning achievement of Musicsthrough time token cooperative learning model in VIII B students of Semester I of SMP Negeri 3 Nguter in the 2017/ 2018 school year. This research was conducted from July to November 2016 in SMP Negeri 3 Nguter. The subjects of this study were students of class VIII B as many as 32 students. This research is a Classroom Action Research conducted in two cycles. Data collection techniques used documentation, observation, and written tests. Data collection tools are observation sheets, test items, and value list documents. Data analysis using comparative descriptive analysis followed by reflection on each cycle consists of four steps, namely: (1) Planning, (2) Action Implementation, (3) observation, and (4) reflection.The results of this study indicate an increase in learning achievement of Musics students. This can be seen from the. The percentage of students' learning mastery, example before the action of $68.2 \%$, in the first cycle of $77.3 \%$ and in the second cycle of $95.5 \%$.In addition, average score of learning achievement of Musics students also experienced an
\end{abstract}


increase before the action of 70.2, in the first cycle of 73.2 and on the second cycle of 82.7. So it can be concluded that "The use of time token cooperative learning model can improve the learning achievement of Musics students of VIII B semester ISMP Negeri 3 Nguter2017/ 2018 academic year".

Keywords: Learning Achievement of Musics, Time Token Cooperative Learning Model.

\section{Pendahuluan}

Dalam kegiatan proses belajar mengajar, kerjasama antara guru dan siswa sangat penting karena seorang guru dituntut untuk mampu menyajikan suatu materi pelajaran dengan maksimal dan mudah di mengerti oleh para siswa. Guru bukan sebagai pusat pembelajaran, melainkan sebagai pembimbing, motivator dan fasilitator. Oleh sebab itu diperlukan kreatifitas dan inovasi-inovasi baru untuk menyajikan materi pelajaran kepada para siswa agar tidak cepat bosan dalam menerima materi-materi baru dan supaya menganggap mata pelajaran seni musik itu tidak susah karena kesulitan yang biasanya dihadapi oleh siswa yaitu pemahaman siswa tentang konsep seni musik yang sangat lemah sehingga beberapa siswa kurang berperan aktif saat proses pembelajaran berlangsung, Berkaitan dengan hal tersebut, permasalahan yang sama terjadi di SMP Negeri 3 Nguter dimana kegiatan pembelajaran hanya berpusat pada guru sehingga kegiatan belajar mengajar menjadi kurang menarik sehingga kurang diminati siswa. Berdasarkan hasil ulangan seni musikmateri pokok Akor pada siswa kelas VIIII A SMP Negeri 3 Nguter, didapatkan $67,5 \%$ siswa yang tuntas melebihi KKM dan rata-rata nilai 71,5 . Jumlah siswa kelas VIIII A sebanyak 32 siswa, KKM Seni musik di SMP Negeri 3 Nguter adalah 70. Arifin dalam Media Pendidikan (2012 : 1) mengemukakan bahwa prestasi belajar adalah kemampuan, keterampilan, dan sikap seseorang dalam menyelesaikan suatu tugas.Gunarso dalam Hengkiriawan (2012 : 2) mengemukakan bahwa prestasi belajar adalah usaha maksimal yang dicapai oleh seseorang setelah melaksanakan usaha-usaha belajar.Dari pengertian tersebut dapat disimpulkan bahwa prestasi belajar matematika yaitu hasil dari usaha belajar maksimal yang sudah dilakukan oleh seseorang dalam menguasai suatu ilmu pengetahuan dan keterampilan berfikir yang menghasilkan perubahan dalam dirinya. Pembelajaran adalah sesuatu yang dilakukan oleh siswa, bukan dibuat untuk siswa. Pembelajaran pada dasarnya merupakan upaya pendidik untuk membantu peserta didik melakukan kegiatan belajar (Isjoni, 2007: 11). Menurut Hamdani (2011: 80), model pembelajaran adalah cara yang digunakan guru untuk menyampaikan pelajaran kepada siswa. Karena penyampaian itu berlangsung dalam interaksi idukatif, Model pembelajaran dapat diartikan sebagai cara yang dipergunakan oleh guru dalam mengadakan hubungan dengan siswa pada saat berlangsungnya pengajaran. Dengan demikian, model pembelajaran merupakan alat untuk menciptakan proses belajar mengajar. Menurut H. Karli dan Yuliariatiningsih (Hamdani, 2011: 165), model pembelajaran kooperatif adalah suatu strategi belajar mengajar yag menekankan pada sikap atau perilaku bersama dalam bekerja atau membantu diantara sesama dalam struktur kerja sama yang teratur dalam kelompok, yang terdiri atas dua orang atau lebih. Keberhasilan kerja sangat dipengaruhi keterlibatan setiap anggota kelompok itu sendiri. Dalam Suprijono (2009 : 46) Model pembelajaran ialah pola yang digunakan sebagai pedoman dalam merencanakan pembelajaran dikelas 
maupun tutorial. Menurut Arends, model pembelajaran mengacu pada pendekatan yang akan digunakan, termasuk didalamnya tujuan-tujuan pembelajaran, tahap-tahap dalam kegiatan pembelajaran, lingkungan pembelajaran, dan pengelolaan kelas. Model pembelajaran dapat didefinisikan sebagai kerangka konseptual yang melukiskan prosedur sistematis dalam mengorganisasikan pengalaman belajar untuk mencapai tujuan belajar. Keunggulan model pembelajaran Time Token yaitu membagun suatu kerja sama antar siswa dalam tiap kelompok, bertanggung jawab terhadap penguasaan materi yang sudah diberikan baik secara individu maupun kelompok, hasil kerja kelompok dapat dirasakan bersama sehingga setiap siswa dapat bekerja secara aktif dalam kelompoknya masing-masing mendiskusikan jawaban yang benar dari soal yang diberikan oleh guru sehingga hasil prestasi seni musik dapat ditingkatkan. Langkah-langkah model pembelajaran kooperatif Time Token menurut Arends (1998: 58) adalah: (1) kondisikan kelas untuk melaksanakan diskusi (cooperative learning/CL); (2) tiap siswa diberi kupon berbicara dengan waktu sekitar 30 detik, tiap siswa diberikan sejumlah nilai sesuai waktu yang digunakan; (3) bila telah selesai bicara, kupon yang dipegang siswa diserahkan; setiap berbicara satu kupon; (4) siswa yang telah habis kuponnya tak boleh bicara lagi, yang masih pegang kupon harus berbicara sampai kuponnya habis; dan (5) dan seterusnya. Berdasarkan uraian diatas, maka dapat dirumuskan tujuan penelitian ini adalah untuk meningkatkan prestasi belajar seni musik dengan penerapan model pembelajaran kooperatif Time Token Time Token pada siswa kelas VIII Bsemester II SMP Negeri 3 Nguter tahun pelajaran 2017/ 2018. Prestasi belajar seni musik siswa pada penelitian ini dibatasai pada prestasi belajar seni musikmateri pokok Akor.

\section{Metode Penelitian}

Penelitian ini adalah Penelitian Tindakan Kelas (PTK), atau disebut juga Classroom Action Research (CAR). Penelitian tindakan kelas merupakan suatu pencermatan terhadap kegiatan yang sengaja dimunculkan, dan terjadi dalam sebuah kelas (Arikunto, 2010: 130).Penelitian ini dilaksanakan di SMP Negeri 3 Nguter. Tahap-tahap pelaksanaan kegiatan dilakukan selama kurang lebih selama 5 (lima) bulan yaitu bulan Juli s.d Nopember 2016. Peneliti sebagai guru seni musik SMP Negeri 3 Nguter bertindak sebagai subjek yang melakukan tindakan kelas. Kepala Sekolah bertindak sebagai subjek yang membantu dalam perencanaan dan pengumpulan data.Subjek yang menerima tindakan adalah siswa kelas VIII BSMP Negeri 3 Ngutertahun pelajaran 2017/2018 sebanyak 32 siswa. Langkah-langkah penelitian untuk setiap siklus pembelajaran seni musik adalah sebagai berikut:

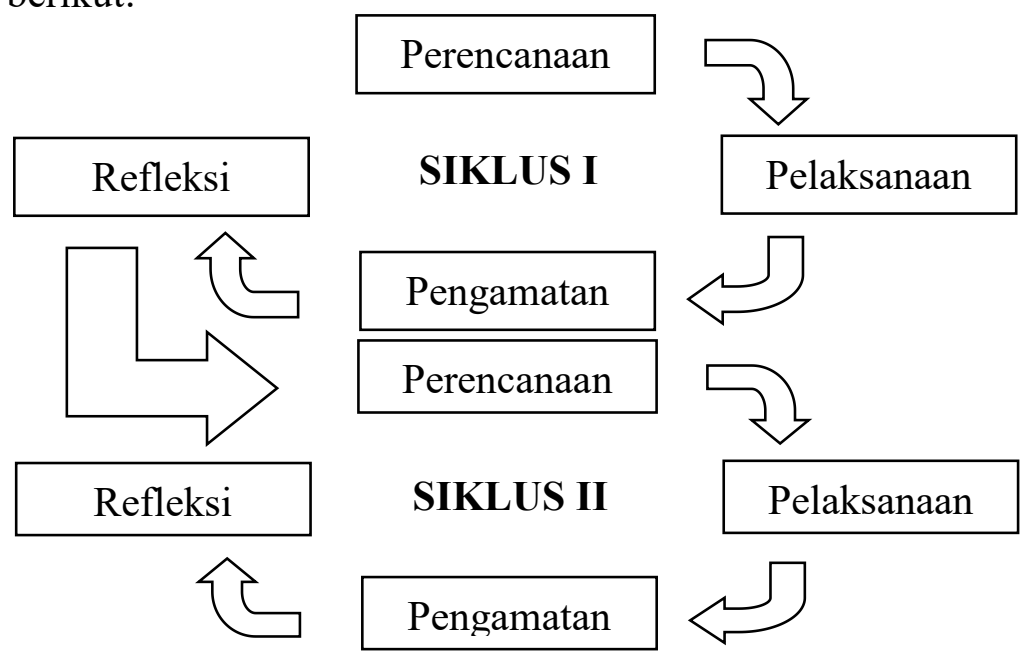


Gambar 1.Siklus Penelitian Tindakan (Arikunto, 2010:137)

Teknik pengumpulan data yang digunakan adalah: (a) Tes, observasi, dan dokumentasi. Tes adalah serentetan pertanyaan atau latihan serta alat lain yang digunakan untuk mengukur keterampilan, pengetahuan inteligensi, kemampuan atau bakat yang dimiliki oleh individu dan kelompok (Arikunto, 2010 : 193). Metode tes digunakan untuk memperoleh data tentang prestasi belajar seni musik siswa sebelum penelitian, selama penelitian dan setelah penelitian dilaksanakan.Observasi yang digunakan adalah observasi sistematis, yaitu observasi yang dilakukan oleh pengamat dengan menggunakan pedoman sebagai instrumen pengamatan. Instrumen yang digunakan dalam penelitian ini adalah: lembar observasi, dan tes.Lembar observasi digunakan untuk memonitor danmengevaluasi setiap tindakan agar kegiatan observasi tidak terlepas dari kontekspermasalahan dan tujuan penelitian.Tes digunakan untuk melihat seberapa besar prestasi dan aktivitas belajar siswa terhadap materi yang diajarkan.Hasil tes dianalisis gunamengetahui prestasi belajar siswa setelah dilakukan pembelajaran kooperatif Time Token. Indikator keberhasilan kinerja dalam penelitian ini adalah meningkatnya prestasi belajar siswa yang ditunjukkan dengan meningkatnya persentase ketuntasan siswa minimal $85 \%$ dan meningkatnya nilai rata-rata kelasminimal menjadi 80,00.

\section{Hasil Penelitian}

Kondisi awal dapat diketahui dengan melakukan kegiatan observasi di kelas VIII BSMP Negeri 3 Nguter. Kegiatan observasi awal ini dilakukan untuk mengetahui keadaan sebenarnya pada proses pembelajaran seni musikyang ada di lapangan. Berdasarkan observasi awal dengan teman sejawat diketahui bahwa siswa kelas VIII Bmemiliki prestasibelajar rendah yang disebabkan karena kurangnya perhatian dan keaktifan dari siswa saat pembelajaran dengan model ceramah. Berdasarkan hasil pretest materi pokok Akor pada siswa kelas VIII BSMP Negeri 3 Nguter,dari 32siswa yang mencapai nilai KKM yaitu 70 sebanyak 15 siswa $(67,5 \%)$ dan siswa yang tidak mencapai nilai KKM sebanyak 12 siswa $(37,5 \%)$ dengan nilai rata-rata kelas sebesar 71,5. Guru hanya menerapkan modelceramah dan siswa hanya disuruh mendengarkan dan mencatat apa yang diperlukan. Hasil ini dapat ditampilkan pada grafik berikut.

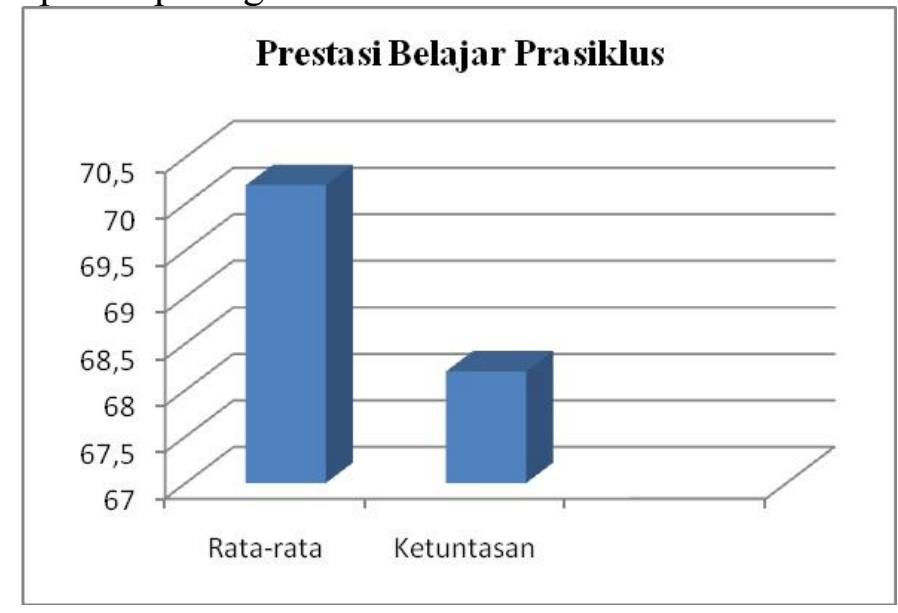




\section{Gambar 2. Grafik Prestasi Belajar Seni musikSiswa pada Prasiklus}

Salah satu solusi yang dikembangkan adalah penggunaan modelpembelajaran kooperatif Time Token. Dengan penggunaan model pembelajaran tersebut diharapkan akan menciptakan suasana belajar yang berbeda, bervariasi dan menyenangkan sehingga dapat menarikperhatian siswa dan meningkatkan prestasi belajar siswa. Pembelajaran dilaksanakan dengan pedoman Rencana Pelaksanaan Pembelajaran (RPP) selama 2 jam pelajaran ( 2 x 40 menit). Materi yang disampaikan pada siklus I adalahMengaransir secara sederhana karya lagu etnik Nusantara dalam bentuk ansambel. Model pembelajaran Time Token dilaksanakan dengan menggunakan langkah-langkah sebagai berikut: (1) Pendahuluan berisi kegiatan guru memberi salam, mengkondisikan kelas, dan mengecek presensi siswa. Guru menyampaikan tujuan pembelajaran yang ingin dicapai dan memberi motivasi belajar; (2) Kegiatan inti tentang pelaksanaan kegiatan model pembelajaran kooperatif Time Token, adapun langkah-langkah kegiatannya sebagai berikut: (a) guru membagi siswa menjadi 4 kelompok, tiap kelompok beranggotakan 4-5 siswa; (b) tiap siswa diberi kupon mengaransirdengan waktu sekitar 30 detik, tiap siswa diberikan sejumlah nilai sesuai waktu yang digunakan; (c) bila telah selesai bicara, kupon yang dipegang siswa diserahkan; setiap mengaransirsatu kupon; (d) siswa yang telah habis kuponnya tak boleh bicara lagi, yang masih pegang kupon harus berbicara sampai kuponnya habis. (3) Penutup, berisi kegiatan guru memberikan kesempatan siswa untuk menanyakan hal-hal yang kurang jelas. Kemudian guru memberikan postest, dan memberikan tugas rumah. Dalam tahap pengamatan tindakan ini, ternyata masih banyak siswa yang kurang aktif dan masing kurang bisa beradaptasi dengan model pembelajaran yang baru. Semuanya dapat dilihat pada saat pelaksanaan pembelajaran dengan menggunakan model pembelajaran kooperatif Time Token. Siswa yang kurang aktif cenderung hanya mengikuti arahan dari guru. Hasil observasi menunjukkan bahwa guru telah melaksanakan kegiatan pembelajaran dengan cukup baik, yaitu guru mengajar dengan arah dan tujuan yang jelas. Namun ketika guru menyampaikan materi dengan model pembelajaran kooperatif Time Token, beberapa siswa tampak masih kurang memperhatikan, dan beraktivitas sendiri. Selain itu tidak semua kelompok dapat berdiskusi dengan baik. Setelah guru melaksanakan pembelajaran seni musikdengan model pembelajaran kooperatif Time Token, guru melaksanakan evaluasi kepada siswa untuk mengetahui prestasibelajar siswa dalam mempelajari materi. Berdasarkan hasil evaluasi pada siklus I menunjukkan adanya peningkatan prestasi belajar siswa. Rata-rata prestasi belajar siswa pada siklus I adalah 73,2, sebanyak 17 siswa (77,3\%) mencapai nilai KKM, dan sebanyak 8 siswa (25\%) tidak mencapai nilai KKM. Berdasarkan hasil tersebut dapat diketahui bahwa proses pembelajaran pada siklus pertama sudah meningkatkan prestasi belajar tetapi belum berjalan dengan cukup baik serta belum mencapai indikator kinerja yang diharapkan. Hasil ini dapat ditampilkan pada grafik berikut. 


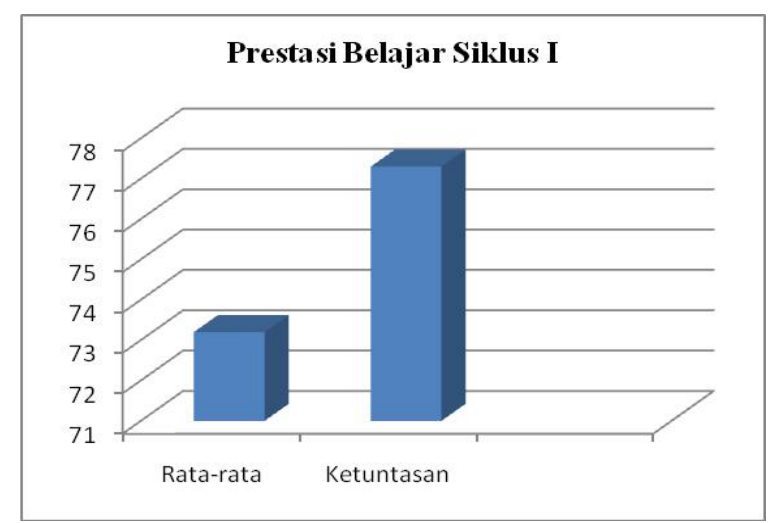

Gambar 3. Grafik Prestasi Belajar seni musikSiswa pada Siklus I

Keberhasilan yang dicapai setelah siklus I hanya sebagian siswa yang menunjukkan partisipasi yang meningkat sementara siswa lainnya masih pasif. Refleksi terhadap faktorfaktor yang menjadi penyebab kurangnya partisipasi siswa adalah: (1) Sebagian siswa belum bisa mengikuti langkah-langkah pembelajaran model pembelajaran kooperatif Time Token; (2) Kerjasama dalam kelompok berdiskusi belum maksimal; (3) Hanya siswa tertentu saja yang dapat memahami materi dan soal yang diberikan kepada setiap kelompok.

Solusi yang diambil untuk mengatasi permasalahan tersebut adalah perlu dilakukan tindakan berikutnya untuk meningkatkan perhatian dan keaktifan belajar siswa dengan meningkatkan antusias siswa untuk mengikuti pembelajaran dengan model pembelajaran kooperatif Time Token, guru memantau siswa pada saat pemberian materi sehingga guru dapat menegur siswa yang kurang memperhatikan dan mendorong keberanian siswa dalam mengungkapkan pendapat ketika siswa belum mengerti tentang materi yang disampaikan oleh guru. Pembelajaran dilaksanakan dengan pedoman Rencana Pelaksanaan Pembelajaran (RPP) selama 2 jam pelajaran (2 x 40 menit). Materi yang disampaikan pada siklus II adalahMenampilkan hasil aransemen karya lagu etnik Nusantara dalam bentuk ansambel.

Model pembelajaran Time Token dilaksanakan dengan menggunakan langkahlangkah sebagai berikut: (1) Pendahuluan berisi kegiatan guru memberi salam, mengkondisikan kelas, dan mengecek presensi siswa. Guru menyampaikan tujuan pembelajaran yang ingin dicapai dan memberi motivasi belajar; (2) Kegiatan inti tentang pelaksanaan kegiatan model pembelajaran kooperatif Time Token, adapun langkah-langkah kegiatannya sebagai berikut: (a) guru membagi siswa menjadi 6 kelompok, tiap kelompok beranggotakan 3-4 siswa; (b) tiap siswa diberi kupon aransemen dengan waktu sekitar 30 detik, tiap siswa diberikan sejumlah nilai sesuai waktu yang digunakan; (c) bila telah selesai aransemen, kupon yang dipegang siswa diserahkan; setiap berbicara satu kupon; (d) siswa yang telah habis kuponnya tak boleh bicara lagi, yang masih pegang kupon harus berbicara sampai kuponnya habis. (3) Penutup, berisi kegiatan guru memberikan kesempatan siswa untuk menanyakan hal-hal yang kurang jelas. Kemudian guru memberikan postest, dan memberikan tugas rumah. Berdasarkan kegiatan observasi, secara garis besar diperoleh gambaran pelaksanaan tindakan siklus II ada peningkatan prestasi belajar siswa. 
Dalam pertemuan ini banyak siswa mampu menjawab soal-soal yang diberikan dengan benar dan baik. Sebagian siswa aktif dalam bertanya dan mengemukakan ide mereka. Siswa juga dapat memahami materi yang telah diajarkan hal ini terlihat dari cara siswa menyelesaikan soal-soal. Setelah guru melaksanakan pembelajaran seni musikdengan model pembelajaran kooperatif Time Token pada materi cara mengoperasikan sesuatu maka guru melaksanakan evaluasi kepada siswa untuk mengetahui prestasi belajar siswa dalam mempelajari materi.

Berdasarkan hasil evaluasi pada siklus II menunjukkan adanya peningkatan prestasi belajar siswa. Rata-rata prestasi belajar siswa pada siklus II adalah 82,7sebanyak 21 siswa $(95,5 \%)$ mencapai nilai kriteria ketuntasan minimal (KKM), dan sebanyak 1siswa $(3,1 \%)$ tidak mencapai nilai kriteria ketuntasan minimal (KKM). Hasil ini dapat ditampilkan pada grafik berikut.

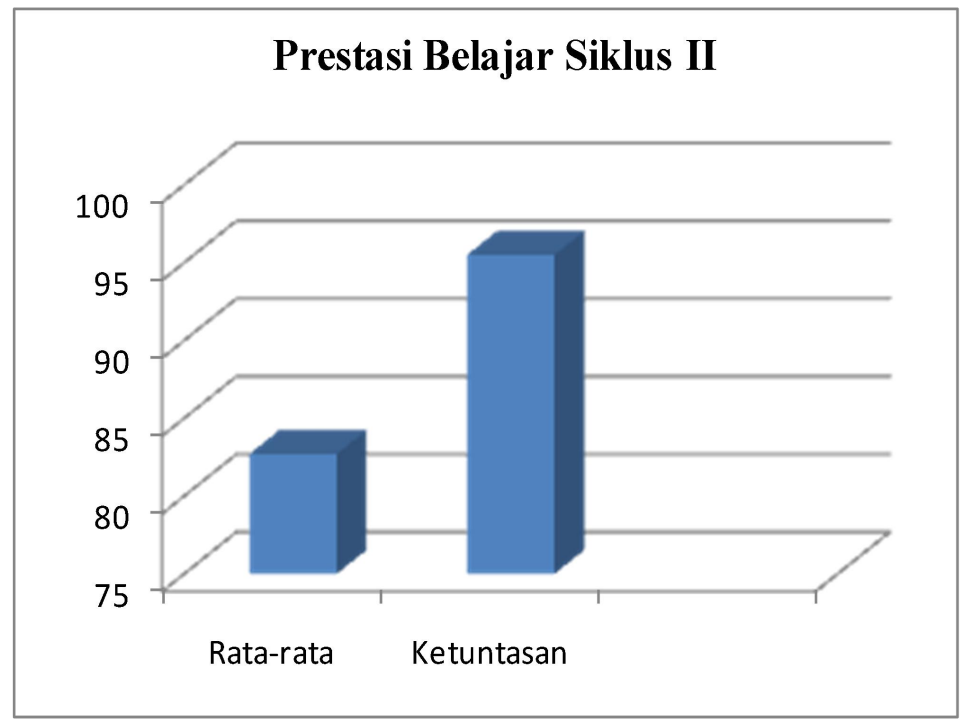

Gambar 4. Grafik Prestasi Belajar seni musikSiswa pada Siklus II

Sebagian siswa menunjukkan partisipasinya meningkat dari siklus I.Keberhasilan yang dicapai setelah siklus II telah memenuhi indikator keberhasilan penelitian ini, sehingga tindakan ini tidak diteruskan atau dihentikan pada siklus II.

\section{Pembahasan}

Berdasarkan pengolahan dan analisis data di atas, maka diperoleh interpretasi bahwa penerapan modelpembelajaran kooperatif Time Tokenterhadap peningkatan prestasi belajar Seni musiksiswa menunjukkan terjadi peningkatanprestasi belajar siswa pada sebelum tindakan ke siklus I, pada siklus I ke siklus II. Peningkatan prestasi belajar Seni musiksiswa sebagai efek dari meningkatnyakepercayaan diri siswa, kerjasama dalam tiap pasangan kelompok dan kemandirian dalam mengerjakan soalserta perhatiaan siswa dalam proses pembelajaran. Hal ini dapat dilihat dari hasil penelitian dari siklus pertama sampai dengan siklus kedua dapat diringkaskan seperti terlihat pada tabel sebagai berikut: Siswa yang mencapai KKM pada saatsebelum tindakan (prasiklus) sebanyak 15 siswa, setelah dilakukan tindakan siklus I sebanyak 17 siswa, setelah tidakan siklus II sebanyak 21 siswa sehingga meningkat 11 siswa. 
Tabel 1. Perkembangan Siswa Sebelum Tindakan, Siklus I dan Siklus II

\begin{tabular}{cccc}
\hline Hasil Siswa & Prasiklus & Siklus I & Siklus II \\
Siswa mencapai KKM & 20 & 24 & 31 \\
\hline
\end{tabular}

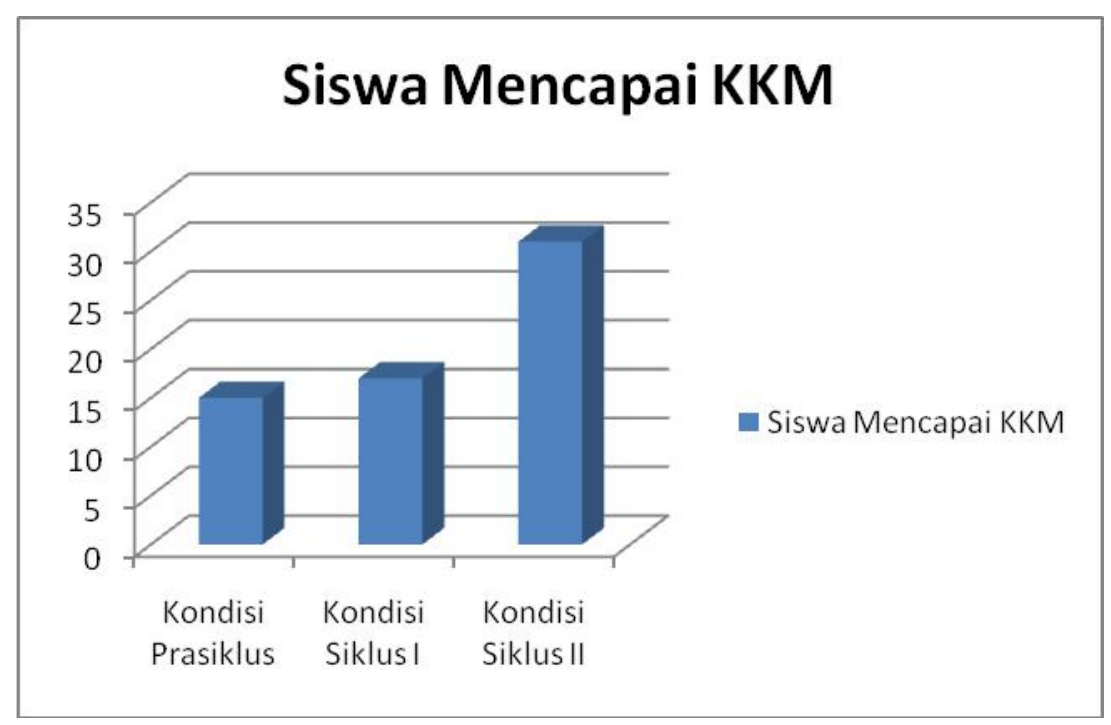

Gambar 5. Perkembangan Siswa Sebelum Tindakan, Siklus I dan Siklus II

Dari grafik di atas dapat disimpulkan bahwa prestasi belajar Seni musiksiswa dengan menerapkan modelpembelajaran kooperatif Time Token, di setiap pelaksanaan tindakan, baik siklus I dan siklus II mengalami peningkatan, yaitu: siswa yang mencapai KKM Sebelum dilakukan tindakan atau prasiklus 15 siswa, setelah tidakan siklus I sebanyak 17 siswa dan setelah tindakan siklus II sebanya 21 siswa, sehingga peningkatan komulatif dari sebelum tindakan/prasiklus sampai dengan siklus II sebesar 11 siswa.

Tabel 2. Perkembangan Persentase Siswa Sebelum Tindakan, Siklus I dan Siklus II

\begin{tabular}{cccc}
\hline Hasil Siswa & Prasiklus & Siklus I & Siklus II \\
\hline Persentase Siswa Mencapai KKM & $68,2 \%$ & $77,3 \%$ & $95,5 \%$
\end{tabular}




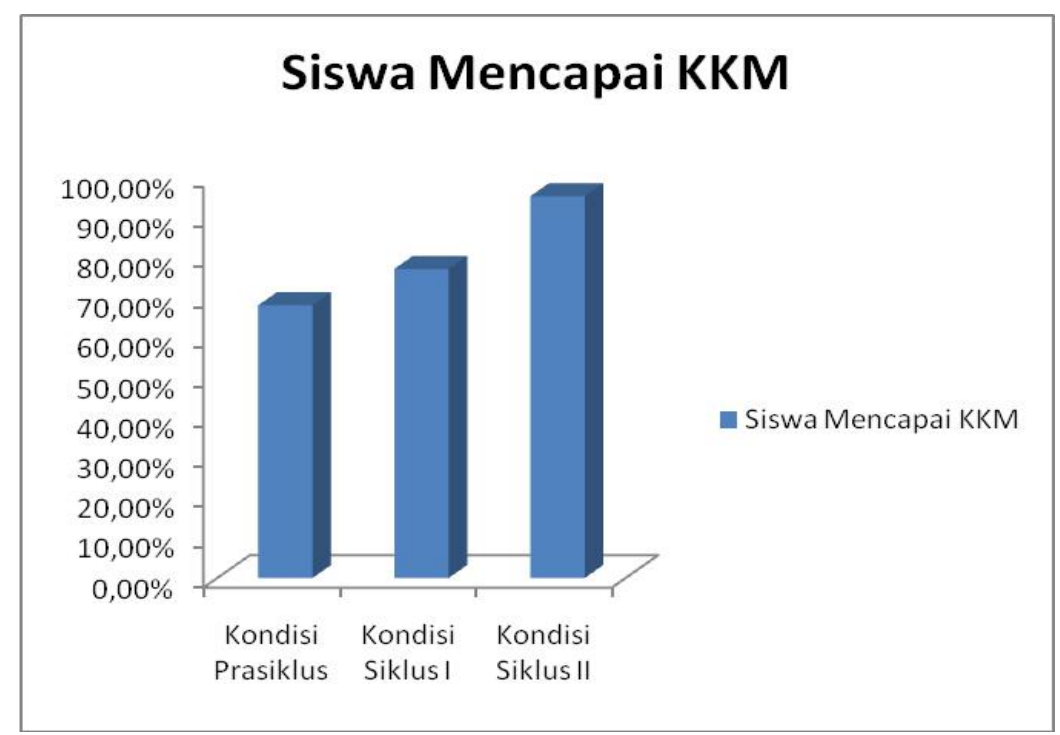

Grafik 6.Perkembangan Persentase Siswa Mencapai KKM Prasiklus, Siklus I dan Siklus II

Dari grafik di atas dapat disimpulkan bahwa prestasi belajar Seni musik siswa dengan menerapkan modelpembelajaran kooperatif Time Token, pada setiap pelaksanaan tindakan mengalami peningkatan, yaitu: persentase siswa yang mencapai KKM Sebelum dilakukan tindakan atau prasiklus $68,2 \%$, setelah tidakan siklus I sebanyak 7\% dan setelah tindakan siklus II sebanya 95,5\%, sehingga terjadi peningkatan prasiklus sampai dengan siklus II. Nilai rata-rata kelas sebelum tindakan adalah 70,27, setelah tidakan siklus I adalah 73,2dan setelah tindakan siklus II adalah 82,7 sehingga terjadi peningkatan.

Tabel 3. Perkembangan Nilai Rata-rata Kelas Prasiklus, Siklus I dan Siklus II

Hasil Siswa

Prasiklus

Siklus I

Siklus II

Nilai rata-rata

70,2

73,2

82,7

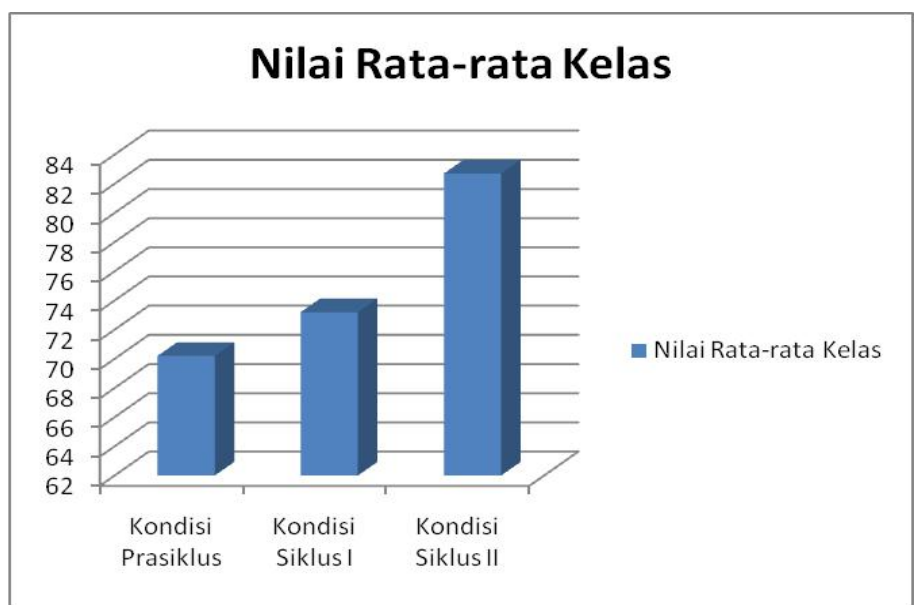

Grafik 7. Perkembangan Nilai Rata-rata Kelas Prasiklus, Siklus I dan Siklus II Berdasarkan grafik di atas dapat disimpulkan bahwa prestasi belajar seni musik siswa dengan menerapkan modelpembelajaran kooperatif Time Tokenpada setiap 
pelaksanaan tindakan mengalami peningkatan, yaitu: nilai rata-rata kelas sebelum dilakukan tindakan atau prasiklus adalah 70,2, setelah tidakan siklus I adalah 73,2dan setelah tindakan siklus II adalah 82,7 sehingga dari kondisi awal sebelum tindakan/prasiklus sampai dengan tidakan pada siklus II terjadi peningkatan.

Tabel 4. Perkembangan Siswa yang Mencapai KKM dan Nilai Rata-rata Kelas Prasiklus, Siklus I dan Siklus II

\begin{tabular}{|l|l|c|c|c|}
\hline No & \multicolumn{1}{|c|}{ Hasil Siswa } & Prasiklus & Siklus I & Siklus II \\
\hline 1. & Siswa Mencapai KKM & 15 & 17 & 21 \\
2. & Persentase & $68,2 \%$ & $77,3 \%$ & $95,5 \%$ \\
3. & Nilai rata-rata kelas & 70,2 & 73,2 & 82,7 \\
\hline
\end{tabular}

Dari uraian di atas dapat disimpulkan bahwa modelpembelajarankooperatif Time Tokendapat meningkatkan prestasi belajarSeni musikmateri pokok Akor pada siswa kelas VIII Bsemester I SMP Negeri 3 Nguter tahun pelajaran 2017/2018.

\section{Simpulan dan Saran}

Hasil penelitian ini menunjukkan bahwa modelpembelajaran kooperatif Time Tokenmodelpembelajarankooperatif Time Tokendapat meningkatkan prestasi belajarSeni musikpada siswa kelas VIII Bsemester I SMP Negeri 3 Ngutertahun ajaran 2017/ 2018.Hal ini dapat dilihat dari persentase ketuntasan belajar siswa, yaitu: sebelum tindakan 15 siswa atau $68,2 \%$, pada siklus I sebanyak 17 siswa atau77,3\% dan pada siklus II sebanyak 21 siswa atau 95,5\%. Sedangkan rata-rata prestasi belajar Seni musik siswa sebelum tindakan sebesar 70,2, pada siklus I sebesar 73,2, dan pada siklus II sebesar 82,7. Pada siklus II nilai siswa yang telah mencapai KKM yaitu95,5\% dan rata-rata prestasi belajar Seni musik siswa 82,7, angka ini menunjukkan bahwa penelitian telah berhasil, karena ketuntasan belajar siswa telah melampaui indikator kinerja yaitu $85 \%$ dan rata-rata prestasi belajar Seni musiksiswa telah melampaui indikator kinerja yaitu 80,0.

\section{Daftar Rujukan}

Arends. (1998). Learning to Teach. New York: MC Grow Hill.Inc.

Arikunto, S. (2006). Prosedur Suatu Pendekatan Praktik edisi revisi 2010. Jakarta: PT Bineka Cipta.

Huda, M. (2011). Cooperative Learning Metode, Teknik, Struktur dan Model Penerapan. Yogyakarta: Pustaka Pelajar.

Nuharini, Dewi dan Wahyuni, Tri. (2008). Seni musik Konsep dan Aplikasinya. Jakarta: Pusat Perbukuan Departemen Pendidikan Nasional.

Suprijono, A. (2009). Coperatif Learning Teori \& Aplikasi PAIKEM. Yogyakarta: Pustaka Belajar.

Wiranataputra, U. S. dkk. (2007). Teori Belajar dan Pembelajaran. Jakarta: Universitas Terbuka. 